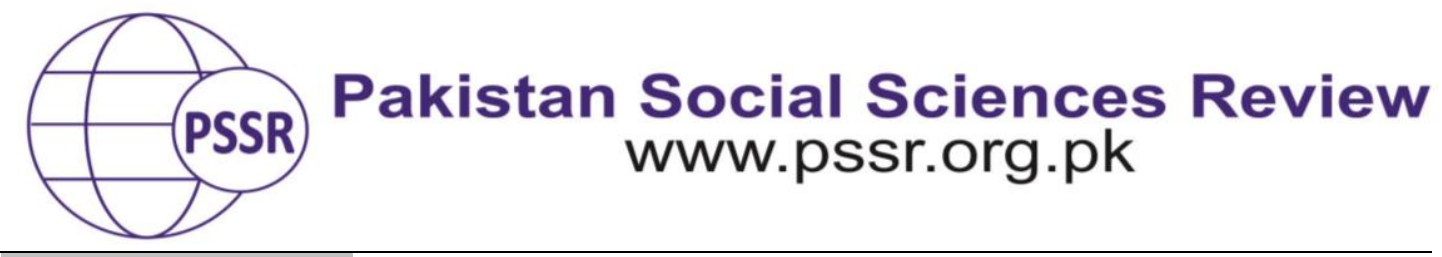

RESEARCH PAPER

\title{
Extremist Narratives of Political Islam in Pakistan in/after 1980s
}

\author{
Muhammad Akram,
}

1. Research Associate at Center for Justice and Peace building Eastern Mennonite University, USA

\begin{tabular}{|c|c|}
\hline 0 & 1 \\
\hline $\begin{array}{l}\text { Rece } \\
\text { Janua } \\
\text { Acce } \\
\text { March } \\
\text { Onli } \\
\text { March }\end{array}$ & $\begin{array}{l}\text { emerged in result of the misuse of political Islam concept during } \\
\text { mans. This concept of political Islam was hijacked and } \\
\text { military establishment. This article makes the situation analysis } \\
\text { in local and regional contexts. It also highlights current shifts in }\end{array}$ \\
\hline $\begin{array}{l}\text { Keywords: } \\
\text { Political Islam, } \\
\text { Muslims, } \\
\text { Pakistan, } \\
\text { Violent Extremism, } \\
\text { Religious }\end{array}$ & $\begin{array}{l}\text { thought with the alleged supported of the military } \\
\text { establishment. Military establishment and political parties } \\
\text { always tried to have their vested interests fulfilled through } \\
\text { religiously extremist groups in the country. The religious } \\
\text { groups, too, tried to heap the benefits for themselves } \\
\text { underhand. The strange nexus between the two kept on } \\
\text { worsening the situation as both sides used the ignorant or the }\end{array}$ \\
\hline $\begin{array}{l}\text { Corresponding } \\
\text { Author: } \\
\text { muhammad.akr } \\
\text { am@emu.edu }\end{array}$ & $\begin{array}{l}\text { th pubic nefariously. With practice approach, this paper } \\
\text { ts theories of change and their potential intervention } \\
\text { to help understand stakeholders the misuse of political } \\
\text { n Pakistan. Such understanding may help the masses of } \\
n \text { in developing the ways to counter the propagated } \\
t \text { of political Islam. }\end{array}$ \\
\hline
\end{tabular}

\section{Introduction}

In terms of violent extremism, year 1979 reshaped the world with the start of Soviet-Afghan war which led to kill more than one million civilians in nine years (Taylor, 2014), and the Iranian revolution which deepened the divided among Muslims in the modern world (Maloney \& Razipour, 2019). These two incidents pushed the neighboring Pakistan, recently broken from its eastern part in 1971 called as Bangladesh today, into a critical phase of finding its place in the changed regional and global contexts but in the leadership of a military ruler (Zia-ul-Haq) whose isolated military regime eagerly pushed Pakistan to be used as sanctuary, training ground, and staging area during the Soviet-Afghan War (Hussain, 2005) with welcomed finance from Saudi Arabia to flourish its militancy approach through madrassas (Afzal, 2019a)in Pakistan. Collaborated insurgency of foreign powers from 
the platform of Pakistan pushed the Soviet forces back from Afghanistan after nineyears of violence but left violent narratives on the ground because of no-effort to deradicalize violence poured among people, particularly Pashtuns, in the name of Jihad. Since Pakistan is a Muslim majority country and second largest Muslim population in the world (World Meters, 2019), Zia relied heavily upon Muslim religious leaders to 'purify' his authoritarian regime for popular support. Hence, he introduced several policies and laws towards the hard-line Islamization of the country; e.g. Blasphemy Law and Hudood Ordinance; which further widened the divide among Muslims in the country along with the fearful position of non-Muslims (Asif, 2018).

\section{Stakeholders of Political Islam in Pakistan}

Political environment officially nurtured for violent extremism in 1980s became heaven for some religious leaders to seek their political influence on government institutions, politicians to find the political interests in religious grounds, and military establishment to strengthen power interests in state institutions. Since then, this nexus of power opportunists found alterable political Islam as the most effective tool to reap their individual interests at the cost of growing radicalization and violent extremism among the people of Pakistan which placed the country itself at critical stage of sectarian violence, instability, and extremism latent in claims of posing the true version of Islam. Violent narratives of political Islam in Pakistan are based on the political interests of power stakeholders who often support their aims and activities with a lot of manipulated examples from the history and teachings of Islam. Since "political Islam refers generally to any interpretation of Islam that serves as a basis of political identity and action, and more specifically the movements representing political mobilization in name of Islam"(Voll \& Sonn, 2014), power stakeholders in Pakistan has well played with this concept for their individual political interests knowing the fact of minimal trend among Muslims to study and research about their own religion by themselves which has allowed power seekers to interpret and present it based on their political power interests.

"When answering the question of who speaks for Islam within Pakistan, we are often misled by the notion of Islam itself" (Villox, 2014a).

\section{Political Nexuses of Islamist Parties}

Politics in Islam is not forbidden if the public welfare is centric, but it is not the case in Pakistan. Since Islam is not uniform in Pakistan, it has different schools of thought and faith traditions mainly divided into Sunni and Shia which are further divided into many faith traditions who are constantly and individually in attempt to define what it means to be a Muslim in Pakistan. Apart from the major traditions of Sunni and Shia, their sub traditions are also in serious theological, ideological, and educational conflict among themselves, and always sought political support for their faith tradition's dominance in the country with all-seasons cry of 'Islam in danger' (Willox, 2014b). Since the 1980s, when Saudi Wahhabism poured its ideology and finance to fight with Soviet Union in Afghanistan, Deobandi school of Sunni Islam got 
dominance in Pakistan and recruited fighters and later remained dominant in the country's political circles through establishing their own parties and alliances with the sitting governments. Jamiat Ulema Islam, a Deobandi religio political party, is known for such alliance with almost all governments after 1980s (Puri, 2009), and Sipah- eSahaba Pakistan, a designated extremist organization, also kept its alliance with political governments of Pakistan Muslim League and Pakistan People's Party (Stanford, 2012).

When the public rejected the heavily political narratives of religious parties in general elections of 2018 and the winning political party, i.e. Pakistan Tehreek-e-Insaf, refused to have alliance with Deobandi led party; they made alliance with grand opposition in protests and even brought madrassa students in their political rallies (Ali, 2019). Apart from political alliances, Deobandi and Salafi seminaries continued to receive the Saudi finance to promote Saudi version of Sunni Islam in Pakistan, and to counter Shia narratives from Iran (Afzal, 2019b) which has pushed the masses into the violent extremism as both sects constitute around 96 percent of the country's population.

"Allah does not forbid you from those who do not fight you because of religion and do not expel you from your homes - from being righteous toward them and acting justly toward them. Indeed, Allah loves those who act justly." quran.com/60

\section{Flourishing Times of Islamist Parties' Political-Base}

Religious parties flourished their political bases significantly during the military regimes who found those helpful to legitimize their coups before faithblinded public, e.g. the extremist and narrowed approach of Islam in Zia regime, the accommodation of Muttahida Majlis-e-Amal, an alliance of right-wing religious parties, in the Musharraf regime (PeaceInsight, 2019; International Crisis Group, 2003) which gave new heights to such alliances. Whenever military was not in regime, there is also a significant amount of connecting dots when it uses establishment to invoke religious sentiments to control local politics, e.g. the sit-ins in Islamabad by Pakistani Awami Tehreek in 2013 (Khan \& Mullen, 2013) and by Tehreek-e-Labbaik in 2018 (Waseem \& Azeem, 2017). Such examples may also be tracked back in 1990s when such invisible hands played their role to destabilize political governments (Javaid, 2011).

\section{Shia Muslims' Politics and their Extremist Engagements}

As Pakistan has been fertile for grounding the extreme sectarian narratives for political grounds implanted both by the internal and external factors, this fertility not only embraced the followers of Sunni tradition of Islam but also of Shia as Pakistan has biggest Shia population outside Iran, i.e. 5-20 percent (UNHCR, 2013). When military regime in 1980s was supporting ideologies of Wahhabism among Deobandi and Barelvi Muslims, Islamic Revolution in Iran offered support and finance to the Shia Muslims in Pakistan to promote 'pure Islam'to establish the pro-Shia Tehreek-e- 
Nafaz- e-Fiqah-e-Jafaria (TNFJ) followed by Sipah-e-Muhammad Pakistan (SPM) in 1990s. It propagated its narratives among local populations (Hunzai, 2013). Thus, same decade pushed the people of Pakistan into proxy war in the name of religion, and its pursuanceof finding true Islam, funded by Saudi Arabia and Iran but unseen battle ground was Pakistan (Johnson et al, 2016). The so-calledIslamic ideologiesof Saudi Arabia and Iran imported and promoted violence in Pakistan and divided the local populations for political interests based on their affiliation to religious party. To counter the Saudi narratives and U.S. political interests, it was never a challenge for Iran to support the political and militant Shia groups in Pakistan as it shares 596 miles border with Pakistan.

Tehrik-e-Jafaria Pakistan (TJP), officially considered a Shiite political party in Pakistan, freely acknowledges its close ties with Iran, and with frequent travels of its members to Iran, has twice been banned by the government of Pakistan as a terrorist organization. Similar to Saudi strategy, Iran also has practice to finance buildings for worship, Imam Bargah in Shia case, which serves as a religious diplomacy to strengthen political grounds among local communities. Since the 1980s, Pakistani governments were in significant influence of Saudi Arabia, Shia political parties could not get much political umbrella from political power houses, but politics remained an integral part of their religious campaigns. This utilization of religious affiliations is not only misused in local political contexts of Pakistan but there are intelligence reports of more than 1000 Pakistani-Shia who were recruited by Iran to help fight of Bashar Al-Asad in Syria to secure his regime which is global indicator of the misuse of political Islam. (Ullah \& McKay, 2018)

\section{A Shift of Political Power from Deobandi to Barelvi}

In the history of Pakistan, Barelvi-Sunnis, who constitute 50-60 percent of the Muslim population (Mahmood, 2018), have been considered more tolerant and accommodative for the followers of other schools of thought but the situation abruptly changed in 2016 since the hanging of Mumtaz Qadri for assassinating the then Governor of Punjab due to his alleged blasphemous statements (Basit, 2017) - it would require another article to discuss that particular case. Like the others, BarelviSunnis also consider themselves the followers of pure Islam and the unconditional respect of the Prophet Muhammad (Peace be upon him) is central to theirbelief. The hanging of Mumtaz Qadri led to their activism in political circles of Pakistan from the platform of Sunni-Tehreek which had extremist tendencies and later partnered with Tehreek-e-Labbaik Pakistan, a visible violent narrative among Barelvi-Sunni's politics (Zahid, 2018).

Tehreek-e-Labbaik Pakistan came into the limelight in 2017 when they made Federal Law Minister resign after three-week long sit-in at Islamabad due to his alleged effort to amend the clause of the finality of Prophet Muhammad (Peace be upon him) in an oath taking document of election office. In that success over the country's political government, Tehreek-e-Labbaik Pakistan found their political missions and utilized the same religious reasoning and following in its political 
campaign for the general elections of 2018 which surprised with their emergence as fourth largest political party in country. The emergence of Tehreek-e-Labbaik have massively spread the violent political narratives at the street level mainly in Punjab province which was previously less by the other schools of thought.

Another Canada-based Barelvi-Sunni scholar, Tahir-ul-Qadri who heads his political party in Pakistan named Pakistan Awami Tehreek, also reaps his political fruits through the extremist narratives in name of establishing pure Islam in Pakistan. Both of these parties have been in close connections with the military establishment as they consider the elected political governments in the country as corrupt and antiIslamic (Sevea, 2018).

\section{Violence of Political Islam in Pakistan}

The Islamist parties in Pakistan adopt violence in their political narratives for establishing and sustaining close networks with militant groups in order to leverage their pressure upon state of Pakistan; even seek and broaden their vote-bank among the masses as Pakistani population is perceived to be driven by the religious sentiments (Siddiqui, 2019), and are open to be hired and manipulated by those in the position of power or finance. Hence, there is no clear leader of Islam in Pakistan and same is the case with their parties which they form to use as a cover of religion to achieve their political interests; and the faith of the most of Muslims is derived by their unquestioned religious leaderships and authority. Religion is a unifying force here as Islam, but that is not the case in Pakistan where it is used to divide its followers (Tarar, 2019).

\section{Theories of Change}

Since the extremist narratives of political Islam in Pakistan are complex and complicated with an influence from a range of factors from within and outside of the country, there is need of holistic approach to respond the situation to counter the extremist narrative of political Islam in Pakistan. There can be different approaches to counter the situation as following;

To respond the situation of political Islam in local contexts of Pakistan; the Muslims, regardless of their faith traditions, are in need to revert to the teachings of Islam rather than having blind dependence on their 'self-claimed' religious or spiritual leaders.

Ifthe Muslims in Pakistan are sensitized in consulting directly to their holy scriptures, i.e. Quran and Hadith, to be guided on the inclusive state-building and rejection of violence; thenthe violent narratives of the political stakeholders can be countered with nonviolent approach; because lack of religious education on state and politics places common people at critical stage of religious illiteracy which invite the power stakeholders to misuse their religious sentiments for their political and power interests. 
Hence, the increased direct knowledge on religious teachings on state and politics will enable common people to analyze the politically driven religious contexts of their country before giving a thought to the violent narratives of religious, political, or state leaders.

Whereas on the state level of Pakistan, there is significant need to initiate a legislation process of discouraging the misuse of religion and religious sentiments in political and state affairs.

If the state laws and/or constitution discourage the political patterns of misusing religion for personal or political interests, thenthe amount and intensity of violence in the name of Islam will be significantly reduced in Pakistan, becausethe people in Pakistan are faith-oriented whose faith is derived by the so called political pundits and religious clerics; and lack of laws and certain articles in constitution provides them sufficient space for their political and personal interests.

Of course, it will be challenging to introduce, incorporate, and implement such legislations but it will restrict power-seekers to misuse the concept of political Islam in Pakistan.

Since the media is a powerful source for awareness, media houses in Pakistan hold major responsibility at their shoulders regardless of freedom challenges and personal interests of finance and rating.

If media houses realize their responsibility to highlight drivers and actors of violent narratives of political Islam in Pakistan, thenthe tendency of misusing religion in the political contexts of seeking or sustaining power will be reduced, becausethe power stakeholders will be afraid of losing public credibility of misusing people's faith sentiments as people will be better aware of the spirit of political Islam in the interest of the changing contexts of state and society.

The responsible role of the media houses to counter the violent narratives of political Islam will help the common people analyze the political situations and statements in country before they make any affiliation and contribution in such violent narratives.

\section{Practice Approach}

To counter the extremist narratives of political Islam in Pakistan emerged during/after 1980s, the above stated theories of change can be supported with specific interventions at different levels in the period of five years, as initial phase. Since multiple stakeholders are involved - and responsible - for current contexts of political Islam in Pakistan, the proposed interventions would be required to adopt holistic approach of interconnected goals of the specific interventions.

\section{Education of Common People on Political Islam}


Awareness campaigns on social media platform, i.e. Facebook which is in direct access of 15.6 percent population of the country (Internet World Stats, 2017a), through geofencing on districts in southern Punjab, northern Sindh, and Khyber Pakhtunkhwa where political use of Islam has been on the rise. The content of these campaigns should not reflect association with any school of thought practiced among the Muslims of Pakistan but originally derived from Quran as there are a range of verses which guide around the subjects of state and politics at the nexus of Islam in the evolution of human societies. These campaigns on social media should not only build the audience but should also engage them through discussion forums and personalized responses to their queries about political Islam in Pakistan and its relevance and/or contradiction with the teachings of Quran.

A week-long course for local religious leaders of the Muslims representing different schools of thought in the selected districts of Pakistan may be organized to promote the spirit of enhanced research on political Islam which may further transfer the knowledge to uneducated or less educated communities at grass-root levels. Since, the platforms of mosque are most successful influencing institution in local contexts of Pakistan which have the power to derive or divert public opinions, but they have been least utilized in political or social contexts of Pakistan which is not compatible with Islamic history as the mosques served as a place of socio-political activism even during the life of Prophet Muhammad (Peace Be Upon Him). Hence, the revival of socio-political spirit of mosques with unbiased education of the local religious leaders can help to educate the common people on political Islam in their local contexts which will prevent them to respond the extremism or violence calls from religious and/or political leaders in the name of Islam. It will also help local religious leaders to understand the factors which the politicians and political religious leaders utilize to propagate extremist narratives through them and their mosque platforms.

Since the concept of local cable television networks is common in Pakistan as a source of entertainment and news updates, jingle messages should be on-aired on those networks in the targeted locations with specific content from Quran on political Islam and how that rejects the extremist or violent ideologies. Such jingles can be recorded with like-minded religious leaders and/or community activists who have the public trust of being nonviolent in their public messages. Since the cable television networks are less expensive digital sources with massive local outreaches, on-airing jingles on them will reach the grass-root communities to listen and analyze teachings of their religion on political Islam and why they should identify and reject the extremist narratives at local politics.

The madrassa students are at critical position between the extremism and political Islam which have been the primary target of being misused by the political religious leaders. There should be self-awareness camps with madrassa students at neutral places to give them the opportunity of self -analysis, political situation in the country, and how Islam preaches for the nonviolent politics to support democracy and rule of law. They should also be sensitized on their critical role in nation building 
with inclusive and accommodative approach for all the citizens in the country on human grounds rather than sectarian ones. Facilitators for such camps should be likeminded religious leaders and social change activists without any political affiliations, similar to content delivery.

\section{Legislation to Prevent Misuse of Political Islam Concept}

Since, the society of Pakistan has always been religion oriented, it would be challenging to initiate and conclude the processes of legislation against the misuse of political Islam concept, and ensure the legislation to be inclusive regardless of faith traditions or ethnic backgrounds and discouraging for the political interests driven use of the concept of political Islam. To pursue this goal, there should be consultative meetings with the elected political representatives to draft, introduce, and support the bill of 'political Islam only for public welfare' which can discourage the use of Islamic reasoning to support certain political party and/or their representative and should be particularly applicable while their public interactions, i.e. political gatherings. Upper and lower houses of the government body, i.e. national assembly and parliament, should ensure orientation of this law to all the elected representatives on biannual basis. An observer committee comprised upon the 5-8 elected representatives in both houses should be established to oversee the application of this law, particularly during the election season.

Since the religious platforms are powerful to build and strengthen local narratives, the state of Pakistan should introduce concrete steps in terms of laws to discourage political engagements from religious platforms such as religious gatherings or gathering of religious parties for political purposes. It is a common trend that the religious gatherings would consider the participation of local political activist as a matter of privilege or influence for their events which they (religious leaders) have to pay back later by participating in their political rallies to announce religious or sectarian support for those political leaders' political agendas which would be selfish in most of the cases in Pakistan. The government of Pakistan should take steps which can minimize or curb this interest-oriented partnership which starts from merely attendance to supporting each other's' ideologies to radicalization of communities particularly youth and then violent extremism in the religious and political circles ultimately. The connection between Rana Sanaullah, a renowned politicians and former Law Minister of Punjab province, and Sipah-e-Sahaba Pakistan (SSP), a Sunni-Muslim organizations which has been massively engaged in ShiaMuslim violence, is real life example of such connection (Georgy, 2013). The preventive laws would help to avoid such cases in future.

The operational sphere of NACTA (National Counter Terrorism Authority, nacta.gov.pk) should consider the monitoring of such political campaigns in the country which misuses the concept of political Islam for their political or personal interests rather than state welfare. As the concept of political Islam is open to be manipulated, it would be challenging to define the preventive limits to curb its misuse, but indicators of violence can be listed to monitor and respond by authority. 
In alignment with its establishment goals, NACTA should not operate only as enforcement agency but a transformative one with contextual sensitive awareness components to educate the people of Pakistan on factors of misusing political Islam leading to violence and extremism in society.

\section{Media and the Prevention of the Misuse of Political Islam Concept}

Since media has emerged as an influencing institution of society, this happened during the previous decade in Pakistan, it has impacted massively the structures and functions at different levels but in diverse directions in the country. Media houses in Pakistan should ensure extremism sensitive reporting, particularly when it comes to political Islam, which is not case at the moment due to their race of ratings and profits. In the broader interest of Pakistani society, they should avoid reporting such gatherings and incidents which project the extremism narratives of political Islam and posing the religious or sectarian threats to the rule of law and democracy in country. The rallies by Tehreek-e-Labbaik Pakistan, Pakistan Awami Tehreek, and Jamiat Ulema Islam are known examples in this case. PEMRA (Pakistan Electronic Media Regulatory Authority, pemra.gov.pk) has the leading responsibility in this regard for introducing and implementing extremism preventive regulations for the media houses.

The role of social media cannot be denied which has rapidly gained the grounds as major source of information and engagement for 15.6 percent population of Pakistan (Internet World Stats, 2017b), mainly youth. Apart from the preventive measures by social media service companies like Facebook or Twitter to detect and filter extremism content via artificial intelligence, there should also be an education program as social media users' initiatives to spot and report content on extremism misusing political Islam. If the users of social media are aware of taking initiative to monitor and report such content as service providers has option of reporting, it will multiply their efforts to counter extremist narratives before they reach their intended audience. Social media platforms themselves can be utilized for this educational initiative with quality message content.

In addition to the social media users' initiative, there should also be the launch of a specific social media monitoring project where a team of researchers and data specialists can continuously monitor the social media contents in the country through advance tech filters to prevent the misuse of political Islam concept. Their major tasks should be the identification of such material on social media and reporting that to the service providers, i.e. Facebook or twitter, directly from their platforms. It will not only a help for the service providers to ensure their platforms a source of peaceful engagements but would also be a great contribution in building a peaceful and inclusive society.

\section{Conclusion}


In current global contexts, conflict dynamics in Pakistan are very complex, complicated, and interconnected with a range of issues in the regional security affairs due to its demographic and geographic status. The country is suffering from shattered economy, fragile political system, and poor governance because of the factor of severe and deep-rooted conflict mainly around the country's majority, i.e. Muslims, who have misled their way of nation building and prosperity by falling a prey to their so called religious clerics. Since the general literacy rate of Pakistan is hardly around 50 percent, top on that people are also not considerably educated about their own religion (i.e. Islam) as well which serve as an opportunity for the extremist-minded leaders in religious and political affairs to misuse their lack of knowledge for their extremist and violent narratives. This culture of abusing the concept of political Islam has become such an accessible and easy practice that it has swallowed religious, moral, and democratic values of opinion makers as well as of institutions. Such situation has resulted current conflict and violence dynamics in the country.

Of course, the current scenario of conflict in Pakistan is complex and complicated but there are still options of reverting back towards democratic and moral values to combat the misuse of political Islam to utilize this concept for communal and inclusive welfare. There are still ways to educate the masses to identify and reject the misuse of political aspects in their religion - Islam, there are still time and resources at government institutions to take necessary steps to avoid and control religion as a tool or weapon of gaining or sustaining political powers, and there is still the role left at the end of media to transform their audience into responsible and civic citizens. All the possible remedies of the misuse of political Islam concept should be taken with inclusive and connected approach that can bridge the ways to support each other with aim of attaining the culture of peace, justice, and democracy in Pakistan rather than the tradition of supremacy, power-greed, and oppression of unprivileged. 


\section{References}

Afzal, M. (2019a). Saudi Arabia's hold on Pakistan. Retrieved from www.brookings.edu/research/saudi-arabias-hold-on-pakistan/

Afzal, M. (2019b). Saudi Arabia's hold on Pakistan. Retrieved from www.brookings.edu/research/saudi-arabias-hold-on-pakistan/

Asif, H. (2018). General Ziaul Haq: The Man to Answer for a Lot that Went Wrong with Pakistan. Herald by Dawn. Retrieved from www.herald.dawn.com/news/1398686

Ali, Z. (2019). Fazl claims he refused NRO to Imran, Sanjran. Dawn News. Retrieved from www.dawn.com/news/1496250/fazl-claims-he-refusednro-to-imran-sanjrani

Basit, A. (2017). New Extremist Religious Groups are Wrecking Pakistan. The National Interest. Retrieved from www.nationalinterest.org/feature/newextremist-religious-groups-are-wrecking-pakistan-23779

Georgy, M. (2013). Insight: Pakistani cleric tries hand at politics. Reuters. Retrieved from www.reuters.com/article/us-pakistan-election-sectarianinsight/insight-pakistan-cleric-tries-hand-at-politicsidUSBRE93J0HE20130421

Hunzai, I. (2013). Conflict Dynamics in Gilgit-Baltistan. United States Institute of Peace, special report. Retrieved from www.usip.org/sites/default/files/resources/SR321.pdf

Hussain, T. (2005). U.S.-Pakistan engagement, the war on terrorism and beyond. United States Institute of Peace. Retrieved from www.usip.org/sites/default/files/sr145.pdf

Immigration \& Refugee Board of Canada. (2013). Pakistan: How Shia Muslims differ from Sunnis; treatment of Shias, particularly in Lahore and Multan; government response to violence against Shia Muslims. Retrieved from https://www.refworld.org/docid/52eba0284.html

International Crisis Group. (2003). Pakistan: The Mullahs and the military. Retrieved from www.crisisgroup.org/asia/south-asia/pakistan/pakistanmullahs-and-military

Internet World Stats. (2017a). Asia marketing research, internet usage, population statistics and Facebook subscribers; Pakistan. Retrieved from www.internetworldstats.com/asia.htm\#pk 
Internet World Stats. (2017b). Asia Marketing Research, Internet Usage, Population Statistics And Facebook Subscribers; Pakistan. Retrieved from www.internetworldstats.com/asia.htm\#pk

Javaid, U. (2011). Genesis and Effects of Religious Extremism in Pakistan. International Journal of Business and Social Science, 2(7), 282-288.

Johnson, D. et al. (2016). Countering Violent Religious Extremism in Pakistan; Strategies for Engaging Conservative Muslims. International Center for Religion and Diplomacy.

Khan, S. \& Mullen, J. (2013). Cleric in Islamabad: 'it's the beginning of the revolution'. Retrieved from www.cnn.com/2013/01/14/world/asia/pakistan-qadrimarch/index.html

Mahmood, S. (2018). The Barelvis' Tilt Towards Extremism In Pakistan. South Asian Voices.

Maloney, S. \&Razipour, K. (2019). The Iranian Revolution - A Timeline of Events. The Brookings Institution.

McKay, H. \& Ullah, M. S. (2018). Iran, in Shadow Proxy War with Saudis, Expands its Pakistan Influence. Retrieved from www.foxnews.com/world/iran-inshadow-proxy-war-with-saudis-expands-its-pakistan-influence

Peace Insights. (2011). Pakistan: Conflict Timeline. Retrieved from www.peaceinsight.org/conflicts/pakistan/conflict-profile/conflicttimeline/

Puri, L. (2009). The Past and Future of Deobandi Islam. Combating Terrorism Center Sentinel, 2(11), 19-23.

Sevea, I. S. (2018). The Rise of Barelvi Political Activism in Pakistan. Institute of South Asian Studies (ISAS) Insights, 520. National University of Singapore.

Siddiqui, N. (2019). Strategic Violence among Religious Parties in Pakistan. Oxford Research Encyclopedias, Politics.

Stanford University. (2012). Mapping Militant Organizations, Sipah-e-Sahaba Retrieved from www.web.stanford.edu/group/mappingmilitants/cgibin/groups/view/147

Sonn, T. \&Voll, J. O. (2014). Political Islam. Oxford Bibliographies. Retrieved from www.oxfordbibliographies.com/view/document/obo9780195390155/obo-9780195390155-0063.xml 
Tarar, M. (2019). Religion is Being Misused in Pakistan to Hunt for Political Power and Electoral Hegemony. Gulf News Asia.

Taylor, A. (2014). The Soviet War in Afghanistan, 1979 - 1989. The Atlantic Council.

Waseem, A. \& Azeem, M. (2017). Faizabad sit-in Ends as Army Brokers' deal. Retrieved from www.dawn.com/news/1373274

Willox, A. (2014a). Voice of Political Islam in Pakistan. Australian Institute of International Affairs.

Willox, A. (2014b). Voice of Political Islam in Pakistan. Australian Institute of International Affairs.

World Meters. (2019). Countries in the World by population (2019). Retrieved from www.worldometers.info/world-population/population-by-country/

Zahid, F. (2018). A New Strand of Islamic Extremism in Pakistan. Real Clear Defence. 